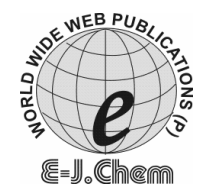

http://www.e-journals.net
ISSN: 0973-4945; CODEN ECJHAO

E-Journal of Chemistry 2010, 7(2), 517-525

\title{
Quantum Chemical Study on Molecular and Electronic Structures of Methyl and Methoxyl Substituted Cu(II) and Ni(II) Benzoic Acid Hydrazides Ions
}

\author{
I. O. ADEOYE, O. A. ODUNOLA, M. A. OLADIPO and B. SEMIRE \\ Department of Pure and Applied Chemistry, \\ Ladoke Akintola University of Technology, \\ P.M.B 4000 Ogbomoso, Nigeria. \\ odunola@yahoo.com
}

Received 30 August 2007; Accepted 20 October 2007

\begin{abstract}
The electronic structures of model methyl and methoxyl substituted benzoic acid hydrazides of $\mathrm{Ni}$ (II) and $\mathrm{Cu}$ (II) complexes have been studied both at semi empirical level (PM3). The ortho-methoxyl is relatively stable which may be due to the formation of hydrogen bonds between methoxyl oxygen and hydrogen on hydrazide $\left(\mathrm{CH}_{3} 0---\mathrm{HNNH} ; 1.817 \AA\right.$ for $\mathrm{Cu}(\mathrm{II})$ and $1.806 \sim 1.839 \AA$ for $\mathrm{Ni}(\mathrm{II}))$. The change in torsion in the complexes affect $\pi$-electrons delocalization (complexes containing $\pi$-electrons system) and consequently affect the band gap which is a measure of electronic properties that control the reactivity of the complexes. The curves for ortho and para methoxyl substituted $\mathrm{Cu}$ (II) complexes intercept at $50^{\circ}$ and $135^{\circ}-144^{\circ}$, this could suggest that both complex ions can co-exist and react in very similar ways in solution under certain conditions.
\end{abstract}

Keywords: Substituent effect, Electronic structure, Benzoic acid hydrazides, Semi empirical, PM3.

\section{Introduction}

The $-\mathrm{CONHNH}_{2}$ moiety of hydrazides have attracted considerable interest in the literature partly because of their coordinating ability to chelate a variety of transition metal ions ${ }^{1-2}$ and their importance of organic chemistry since they are included in retro-bispeptides ${ }^{3-5}$ which are used to design enzyme substrate mimics and potential inhibitors and in aliphatic polyamides $^{6-9}$ which display structures different to the extended conventional ones. However the number of studies about molecular and electronic structures of the hydrazides moiety is scarce ${ }^{10}$. There has been investigation into conformational preferences of hydrazide functional 
groups in both gas phase and aqueous solution using ab-initio quantum mechanical calculations ${ }^{11}$. Recently a number of tin complexes were studied and in any case they seem to manifest efficient anticancer activity ${ }^{12,13}$. The advantage of their use as antitumour medicine lies in their lower costs and possibly in a greater effectiveness. However, in general, a satisfactory understanding of the mode of action of the drug requires a thorough study of its interaction with the relevant biomolecules or their model systems ${ }^{14}$.

Hydrazides generally have also shown a lot of promising biological activity, which could easily lead to their adaptation as a drug. In this paper, the electronic structures and stabilities of substituted Copper(II) and Nickel(II) benzoic acid hydrazides ions were studied using semi empirical method (PM3) (Figure 1).
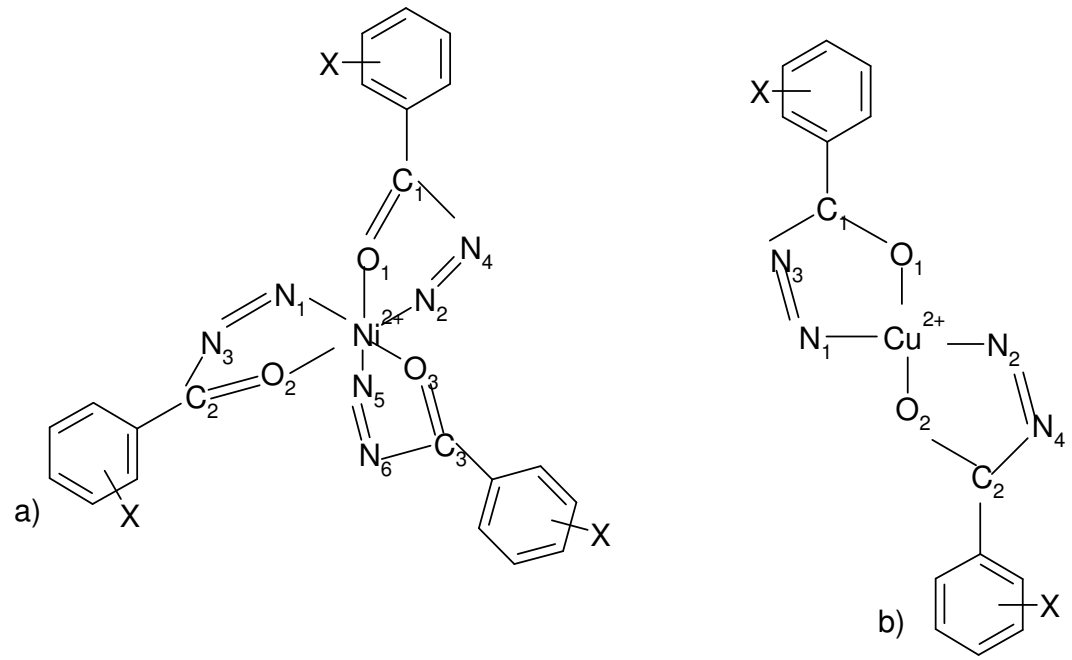

Figure 1. Sketch structures of $\mathrm{M}(\mathrm{II})$ benzoic acid hydrazides ions [a=Cupper(II), $\mathrm{b}=\operatorname{Nickel(II)}$ and $\mathrm{X}=$ methyl or Methoxyl].

\section{Computational details}

The unsubstituted and substituted $\mathrm{Cu}\left[\mathrm{C}_{6} \mathrm{H}_{7} \mathrm{CON}_{2}\right]_{2}{ }^{2+}$ and $\mathrm{Ni}\left[\mathrm{C}_{6} \mathrm{H}_{7} \mathrm{CON}_{2}\right]_{3}{ }^{2+}$ complexes were modeled using Spartan 04 essential $^{15}$. The structures were fully optimized ${ }^{16}$ at the PM3. PM3 method is a computational efficient technique that gives conformation and heats of formation in qualitative good agreement with trend in results of more accurate methods ${ }^{17}$.

\section{Results and Discussion}

\section{Stability and geometry}

Table 1 shows the heats of formation of the two series of $\mathrm{Cu}(\mathrm{II})$ and $\mathrm{Ni}$ (II) benzoic acid hydrazides ions. The stability of the $\mathrm{Cu}$ (II) complex ions increases in the order ortho < meta $<$ para for methyl substituted. However, in methoxyl substituted $\mathrm{Cu}$ (II) complex ions, the stability increases in the order meta < ortho< para (the ortho methoxyl substituted is more stable than the meta substituted). In Ni(II) hydrazide ions, meta-methyl substituted is most stable and ortho-methoxyl substituted is energetically preferred, it is more stable than paramethoxyl substituted. The relative stability of methoxyl may be due to the formation of Hydrogen bonds between methoxyl oxygen and hydrogen on hydrazide $\left(\mathrm{CH}_{3} \mathrm{O}---\mathrm{HNNH}\right.$; $1.817 \AA$ for $\mathrm{Cu}(\mathrm{II})$ and $1.806 \sim 1.839 \AA$ for $\mathrm{Ni}(\mathrm{II}))$ as shown in Figure 2. 
Table 1. Heats of formation $(\mathrm{kcal} / \mathrm{mol})$ and HOMO-LUMO energy difference $(\mathrm{eV})$ as calculated using PM3.

\begin{tabular}{ccccc}
\hline \multirow{2}{*}{ Substitution } & \multicolumn{2}{c}{ Heats of formation, $\mathrm{kcal} / \mathrm{mol}$} & \multicolumn{2}{c}{$\mathrm{E}_{\mathrm{HOMO}-\mathrm{LUMO}}, \mathrm{eV}$} \\
\cline { 2 - 5 } & $\mathrm{Cu}\left[\mathrm{C}_{6} \mathrm{H}_{7} \mathrm{CON}_{2}\right]_{2}{ }^{2+}$ & $\mathrm{Ni}\left[\mathrm{C}_{6} \mathrm{H}_{7} \mathrm{CON}_{2}\right]_{3}{ }^{2+}$ & $\mathrm{Cu}\left[\mathrm{C}_{6} \mathrm{H}_{7} \mathrm{CON}_{2}\right]_{2}{ }^{2+}$ & $\mathrm{Ni}\left[\mathrm{C}_{6} \mathrm{H}_{7} \mathrm{CON}_{2}\right]_{3}{ }^{2+}$ \\
\hline Un-sub. & 330.959 & -140.982 & 7.711 & 7.323 \\
$o-\mathrm{CH}_{3}$ & 311.268 & -136.143 & 6.331 & 5.711 \\
$m-\mathrm{CH}_{3}$ & 304.891 & -171.014 & 6.158 & 6.935 \\
$p-\mathrm{CH}_{3}$ & 301.187 & -171.725 & 6.280 & 6.965 \\
$o-\mathrm{OCH}_{3}$ & 240.757 & -268.942 & 7.493 & 7.238 \\
$m-\mathrm{OCH}_{3}$ & 255.567 & -232.267 & 5.113 & 5.650 \\
$p-\mathrm{OCH}_{3}$ & 236.457 & -262.875 & 6.094 & 6.650 \\
\hline
\end{tabular}

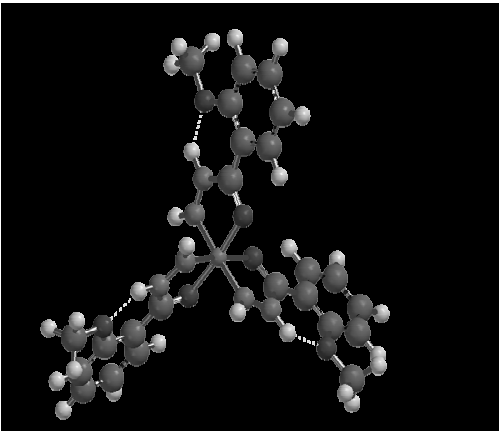

(a)

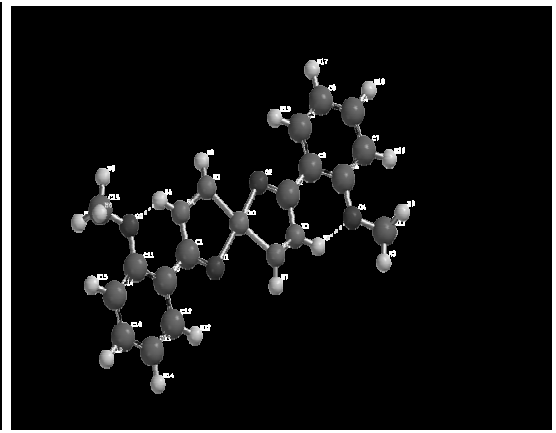

(b)

Figure 2. Ortho-methoxyl substituted showing hydrogen bonds, (a) ortho-methoxyl $\mathrm{Ni}\left[\mathrm{C}_{6} \mathrm{H}_{7} \mathrm{CON}_{2}\right]_{3}{ }^{2+}$ and (b) ortho-methoxyl $\mathrm{Cu}\left[\mathrm{C}_{6} \mathrm{H}_{7} \mathrm{CON}_{2}\right]_{2}^{2+}$.

The trends in stability of these series of complex ions coincide with that of HOMO-LUMO gaps $(\Delta)$; the higher the stability the larger the $\Delta$ gaps. Table 2 shows selected bond lengths and bond angles of the complexes calculated at PM3 level. The bond lengths of $\mathrm{Cu}$ (II) hydrazides are more or less affected with methyl substitution but methoxyl substitution affects bond lengths by shortened $\mathrm{Cu}-\mathrm{O}$ and lengthened $\mathrm{Cu}-\mathrm{N}$ especially for ortho- and para-substitutions. Both methyl and methoxyl substitutions affect copper-hydrazides bond angles $(<\mathrm{CuN} 1 \mathrm{~N} 2$ and $\mathrm{CuN} 3 \mathrm{~N} 4)$ as compared to un-substituted. In case of $\mathrm{Ni}(\mathrm{II})$ hydrazides, greater distortion is noticed in both methyl (except $m-\mathrm{CH}_{3}$ ) and methoxyl substitutions as reflected in bond lengths and bond angles $(<\mathrm{NiN} 1 \mathrm{~N} 3$, NiN2N4 and NiN5N6).

\section{Torsion potentials}

The Torsion potential curves for $\mathrm{Ni}\left[\mathrm{C}_{6} \mathrm{H}_{7} \mathrm{CON}_{2}\right]_{3}{ }^{2+}$ and $\mathrm{Cu}\left[\mathrm{C}_{6} \mathrm{H}_{7} \mathrm{CON}_{2}\right]_{2}{ }^{2+}$ and their substituted derivatives associated with the rotation of the one of CNNC in different directions are shown in Figures 3, 4, 5 and 6. The energy barrier high for the un-substituted and methyl substituted $\mathrm{Ni}\left[\mathrm{C}_{6} \mathrm{H}_{7} \mathrm{CON}_{2}\right]_{3}{ }^{2+}$ (Figure 3) is less than $1.0 \mathrm{kcal} / \mathrm{mol}$ (almost flat). This shows that position (ortho, meta or para) of the methyl substituent is the major determining factor to the stability of the complexes rather than the methyl; this may be due to internal rotation restriction of the complex ions. In the methoxyl substituted $\mathrm{Ni}$ complexes, the energy barrier experienced is not similar to that of methyl-substituted, except in ortho-methoxyl position. The energy barrier experienced in $m-\mathrm{OCH}_{3}$ substituted is about $4.0 \mathrm{kcal} / \mathrm{mol}$, therefore there would be a greater internal rotation in $m-\mathrm{OCH}_{3}$ substituted as compared to other methoxyl positions, which may have substantial influence on the chemical reactivity of the complex (Figure 4). 
Table 2. Selected bond lengths $(\AA)$ and bond angles $\left(^{\circ}\right)$ for $\mathrm{Ni}(\mathrm{II})$ and $\mathrm{Cu}(\mathrm{II})$ hydrazides derivatives.

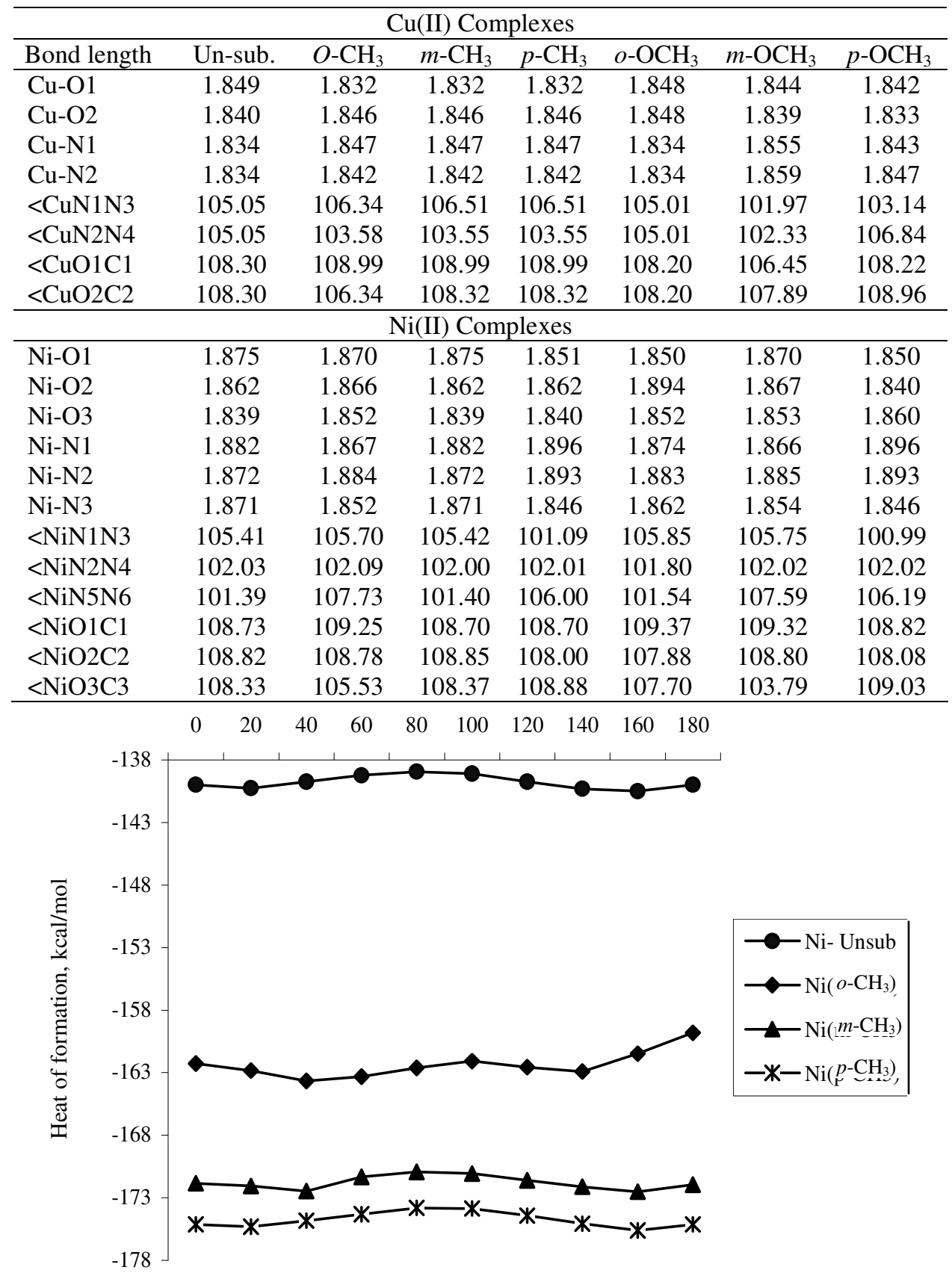

Torsion in degree

Figure 3. Torsion curves of un-substituted, ortho, meta and para-methyl $\mathrm{Ni}_{6}\left[\mathrm{C}_{6} \mathrm{H}_{7} \mathrm{CON}_{2}\right]_{3}{ }^{2+}$. 


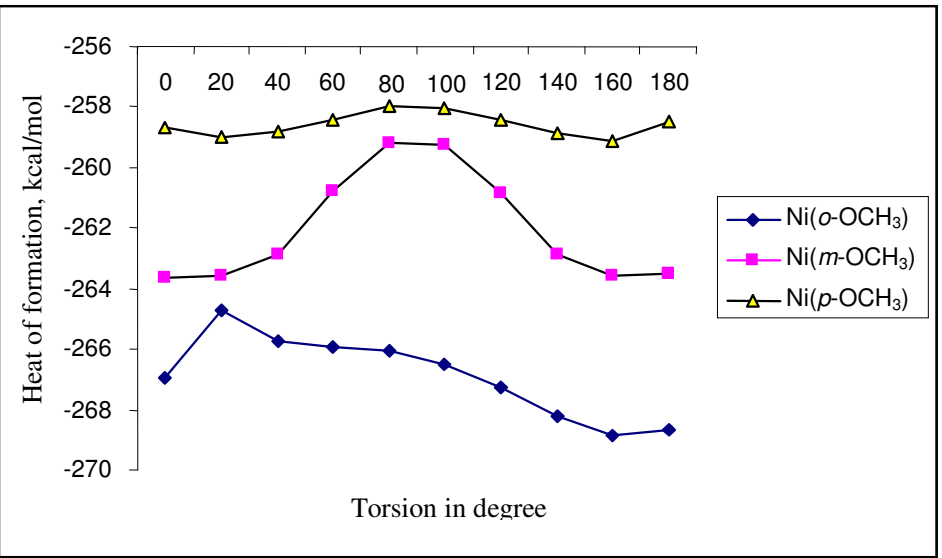

Figure 4. Torsion curves of un-substituted, ortho, meta and para-methoxyl $\mathrm{Ni}\left[\mathrm{C}_{6} \mathrm{H}_{7} \mathrm{CON}_{2}\right]_{3}{ }^{2+}$.

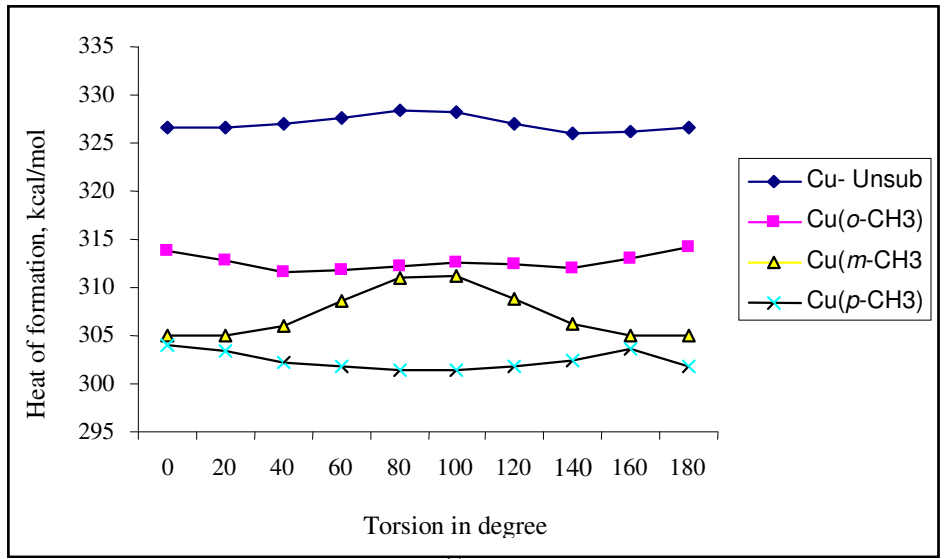

Figure 5. Torsion curves of un-substituted, ortho, meta and para-methyl $\mathrm{Cu}\left[\mathrm{C}_{6} \mathrm{H}_{7} \mathrm{CON}_{2}\right]_{2}{ }^{2+}$.

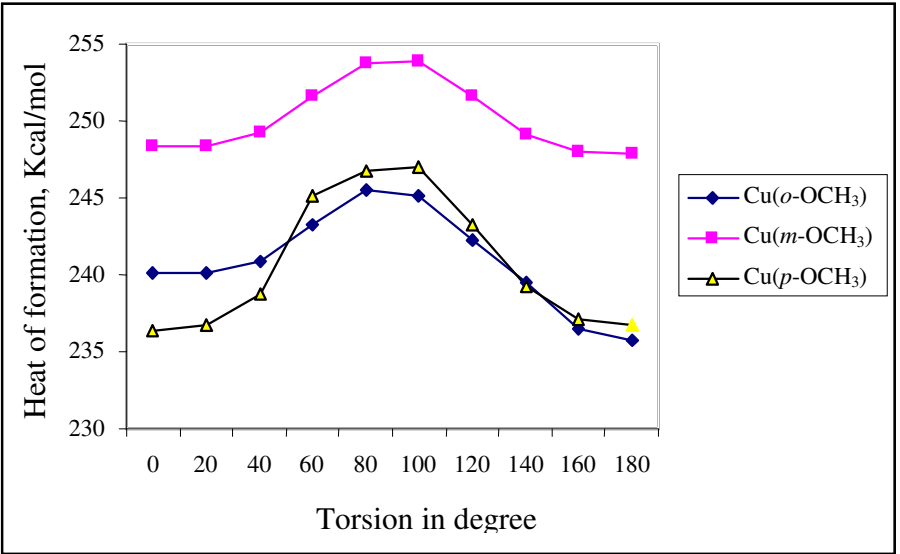

Figure 6. Torsion curves of un-substituted, ortho, meta and para-methyl $\mathrm{Cu}\left[\mathrm{C}_{6} \mathrm{H}_{7} \mathrm{CON}_{2}\right]_{2}{ }^{2+}$. 
In $\mathrm{Cu}\left[\mathrm{C}_{6} \mathrm{H}_{7} \mathrm{CON}_{2}\right]_{2}{ }^{2+}$, the energy barrier experienced on torsion is similar for methyl substituted except in ortho methyl substituted in which barrier height experienced is about $5.0 \mathrm{kcal} / \mathrm{mol}$ (Figure 5). The torsion curves of methoxyl substituted $\mathrm{Cu}$ (II) complex ions are quite similar to that of methoxyl substituted $\mathrm{Ni}(\mathrm{II})$ complex ions (Figure 6). It is very interesting to note that the curves for ortho and para methoxyl substituted $\mathrm{Cu}$ (II) complexes intercept at $50^{\circ}$ and $135^{\circ}-144^{\circ}$, this could suggest that both complex ions can co-exist and react in very similar ways in solution under certain conditions. In general, methoxyl group contribution more to the geometry distortion than methyl substituted in both $\mathrm{Ni}$ (II) and $\mathrm{Cu}(\mathrm{II})$ complexes ions.

\section{Evolution of HOMO and LUMO}

Figure 7, 8, 9 and 10 show the evolution of the HOMO-LUMO energy difference $(\Delta)$ of the two series of substituted $\mathrm{Ni}\left[\mathrm{C}_{6} \mathrm{H}_{7} \mathrm{CON}_{2}\right]_{3}{ }^{2+}$ and $\mathrm{Cu}\left[\mathrm{C}_{6} \mathrm{H}_{7} \mathrm{CON}_{2}\right]_{2}{ }^{2+}$ as a function of torsion angles. As expected, the change in torsion in the complexes affect $\pi$-electrons delocalization (complexes containing $\pi$-electrons system) and consequently affect the $\Delta$ gap which is a measure of electronic properties of the complexes. It is observes that changes in $\Delta$ become prominent with increase in torsion angles.

In $\mathrm{Ni}\left[\mathrm{C}_{6} \mathrm{H}_{7} \mathrm{CON}_{2}\right]_{3}{ }^{2+}$, there is a decrease in $\Delta$ as the torsion angles become larger until $100^{\circ}$ for the un-substituted and substituted except for $m-\mathrm{CH}_{3}$ and $p-\mathrm{OCH}_{3}$ substituted in which the $\Delta$ increases (Figure 7 and 8). The increment in torsion increased the electronic donating effect to the $\pi$-electrons delocalization of the benzoic rings except in $m-\mathrm{CH}_{3}$ and $p-\mathrm{OCH}_{3}$ substituted.

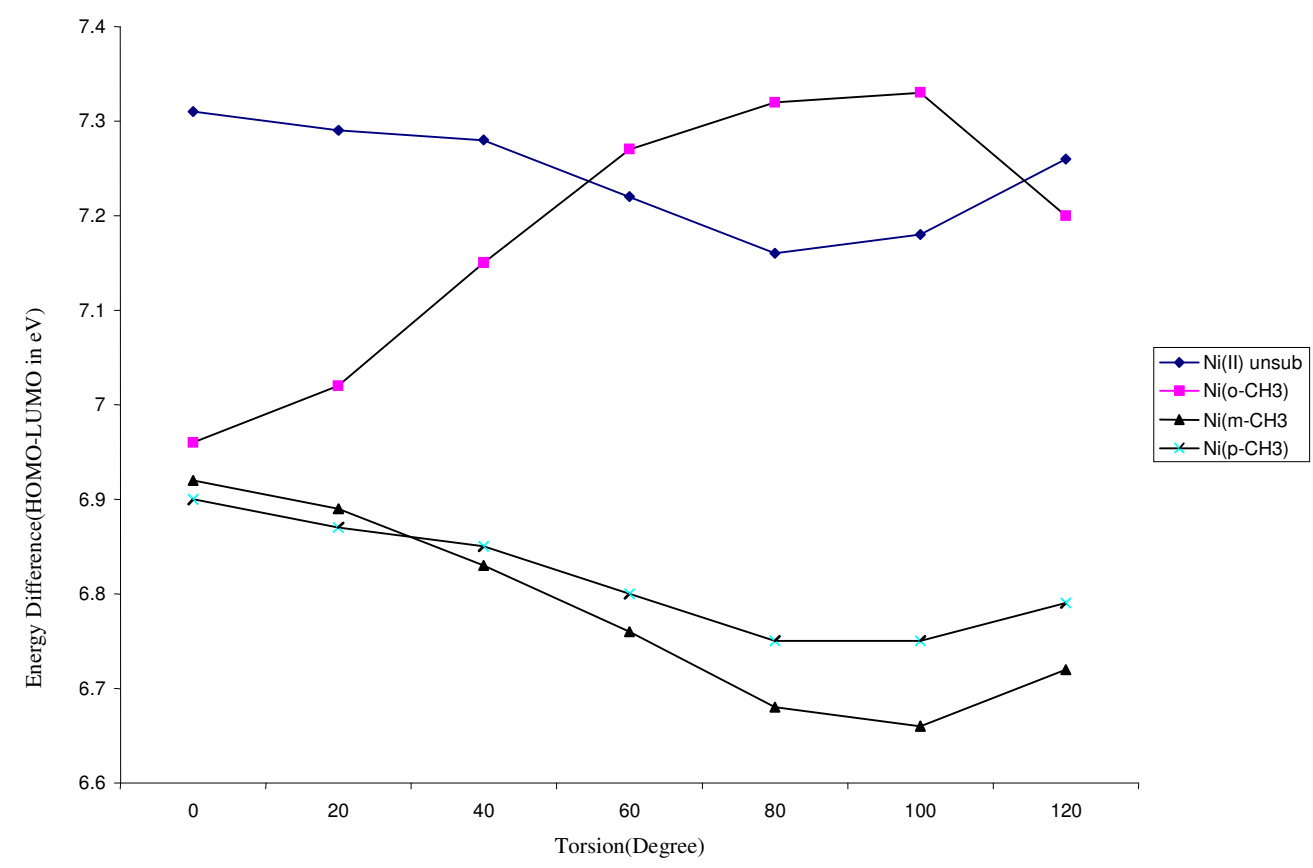

Figure 7. Evolution of HOMO-LUMO energy difference as a function of torsion angles for un-substituted, ortho, meta and para-methyl $\mathrm{Ni}_{[}\left[\mathrm{C}_{6} \mathrm{H}_{7} \mathrm{CON}_{2}\right]_{3}{ }^{2+}$. 


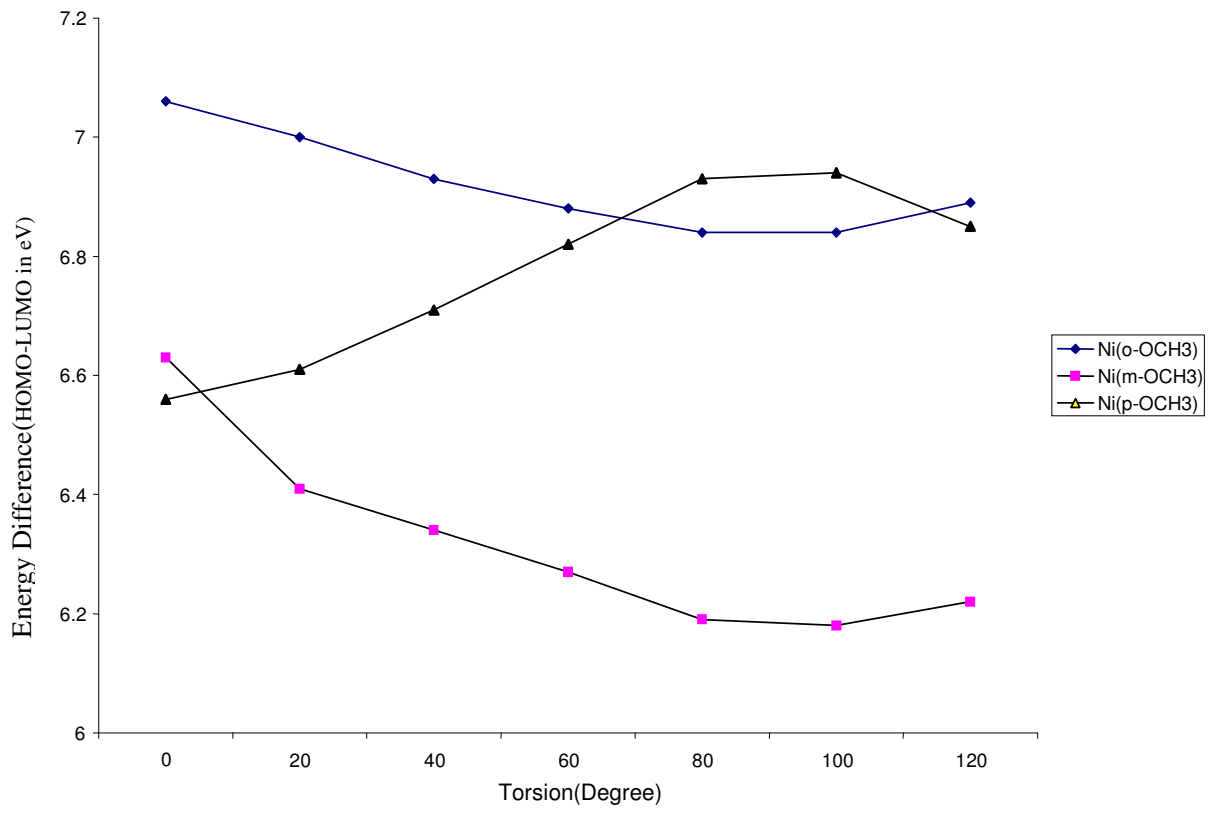

Figure 8. Evolution of HOMO-LUMO energy difference as a function of torsion angles for un-substituted, ortho, meta and para-methoxyl $\mathrm{Ni}\left[\mathrm{C}_{6} \mathrm{H}_{7} \mathrm{CON}_{2}\right]_{3}{ }^{2+}$.

However, in the case of un-substituted and methyl substituted $\mathrm{Cu}\left[\mathrm{C}_{6} \mathrm{H}_{7} \mathrm{CON}_{2}\right]_{2}{ }^{2+}$, the curves are quite similar to that of $\mathrm{Ni}_{2}\left[\mathrm{C}_{6} \mathrm{H}_{7} \mathrm{CON}_{2}\right]_{3}{ }^{2+}$ in that there is a decrease in $\Delta$ gap as the torsion angles become larger in un-substituted and ortho-methyl substituted (Figure 9). In Figure 10, methoxyl substituent has the same effect on the $\pi$-electrons delocalization of benzoic rings in the $\mathrm{Cu}(\mathrm{II})$ complexes. Calculated Mulliken charges on copper and Nickel atoms are $-0.494 \sim-0.351$ and $-0.974 \sim-1.061$ respectively. The charge on copper atom increases on addition of methyl and methoxyl substituents, the effect is more pronounced with methoxyl substituent especially on meta and para positions. However, $o-\mathrm{OCH}_{3}$ substituent has little effect on atomic charge of copper which may due to formation of hydrogen bond. The atomic charge on nickel reduces slightly except $o-\mathrm{OCH}_{3}$ substituted which increased.

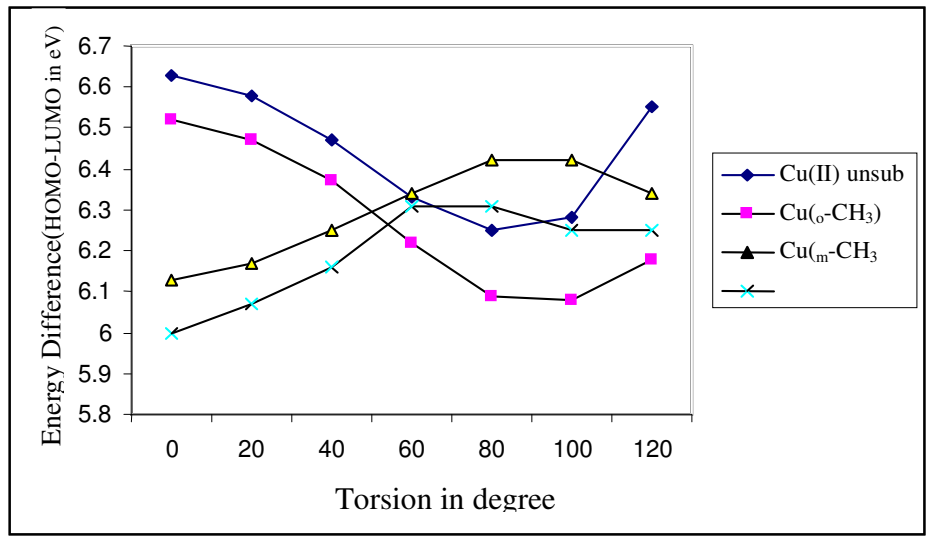

Figure. 9. Evolution of HOMO-LUMO energy difference as a function of torsion angles for un-substituted, ortho, meta and para-methyl $\mathrm{Cu}\left[\mathrm{C}_{6} \mathrm{H}_{7} \mathrm{CON}_{2}\right]_{2}{ }^{2+}$. 


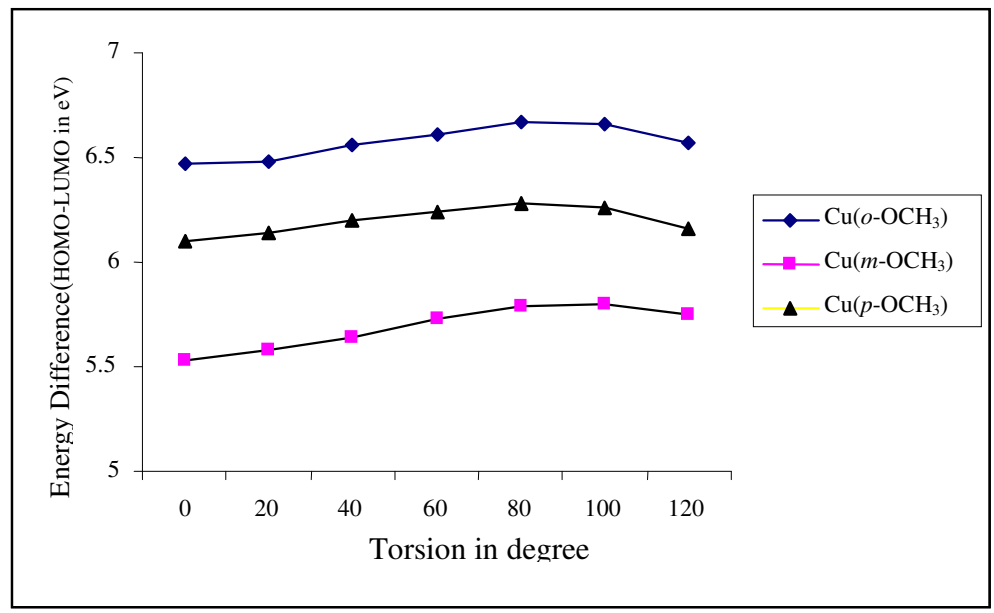

Figure 10. Evolution of HOMO-LUMO energy difference as a function of torsion angles for un-substituted, ortho, meta and para-methoxyl $\mathrm{Cu}\left[\mathrm{C}_{6} \mathrm{H}_{7} \mathrm{CON}_{2}\right]_{2}{ }^{2+}$.

\section{Conclusion}

In order to investigate the electronic effects and geometrical distortions of methyl and methoxyl substituted $\mathrm{Cu}$ (II) and $\mathrm{Ni}$ (II) hydrazides ions, we have utilized the PM3 method. The relative stability of methoxyl substituted may be due to the formation of Hydrogen bonds between methoxyl oxygen and hydrogen on hydrazide $\left(\mathrm{CH}_{3} \mathrm{O}---\mathrm{HNNH}\right.$; $1.817 \AA$ for $\mathrm{Cu}(\mathrm{II})$ and 1.806 1.839 $\mathrm{A}$ for $\mathrm{Ni}(\mathrm{II}))$. Methoxyl substitution has more noticeable effect on the complex ions than methyl substituted which may be due to internal rotations in methoxyl substituted ones.

The curves for ortho and para methoxyl substituted $\mathrm{Cu}(\mathrm{II})$ complexes intercept at $50^{\circ}$ and $135^{\circ}-144^{\circ}$, this could suggest that both complex ions can co-exist and react in very similar ways in solution under certain conditions. In addition, both methyl and methoxyl substituents affect molecular stability of $\mathrm{Cu}$ (II) and $\mathrm{Ni}$ (II) hydrazides complex ions which is good indication that electronic properties control chemical reactivity.

\section{References}

1. Odunola O A, Adeoye I O and Woods J A.O, Synth React Inorg Met Org Chem., 2002, 32(4), 801-817.

2. Odunola O A, Adeoye I O and Woods J A O and Gelebe A C, Synth React Inorg Met Org Chem., 2002, 33(2), 205-221.

3. Ranganathan D, Vaish N K, Shah K, Roy R, Madhusudanan K.P, J Chem Soc Chem Commun., 1993, 92.

4. Karle I, Ranganathan D, Shah K and Vaish N K, Int J Pept Protein Res., 1994, 43, 160.

5. Rosen M K, Standaert R F, Gaalat A, Nakatsuka M, Schereiber S.L, Science, 1990, 248, 863.

6. Chatani Y, Ueda Y, Tadokoro H, Deits W and Vogi O, Macromolecules, 1978, 11, 636-638.

7. Gaymans R.J, Ventatraman V S and Schuijer J, J Polym Sci., Polym Chem Ed., 1984, 22, 1373.

8. Franco L, Subirana J A and Puiggali J, Macromolecules, 1998, 31, 3912. 
9. Frazier A H and Wallenberg F T, J Polym Sci., Part A, 1994, 2, 1147.

10. Aleman C, Lotz B and Puiggali J, J Molecular Structure(Theochem), 2001, 541,179-183

11. Aleman C and Puiggali J, J Org Chem., 1999, 64, 351.

12. Jamieson E.R and Lippard S,.J Chem Rev., 1999, 99, 2467-2498.

13. Gielen M, Biesemans M, de Vos D and Willens R J, Inorg Biochem., 2000,79, 139-145.

14. Henry C Wojciech and Pruchnik F J, Int J Mol Sci., 2001, 2, 148-155.

15 Spartan Essential 2.0.1, Wavefunction, Inc., Irvine 2005.

16 Kong C A, White A I, Kryluv C D, Sharill R D, Adamon T R, Furlani M S, Lec A M, Lee S R, Gwaltney T R, Adams C, Ochsenfeld A T B, Gidert G S, Krddziora V A, Rassollov D R, Maurice N, Nair Y, Shao N A, Bashey P E, Maslen J P, Domobroski H, Daschil W, Zhang P P, Korambath J, Baker E F C, Byrd T, Van V A, Oumi S, Hirata C P, Hsu N, Ishikawa T, Florion A, Warshet B G, Johnson P M W, Gui M, Head-Gordon, Pople J A, J Comput Chem., 2000, 21, 1532.

17 Hehre W J, Wavefunction, Inc. Irvine, USA 2003. 


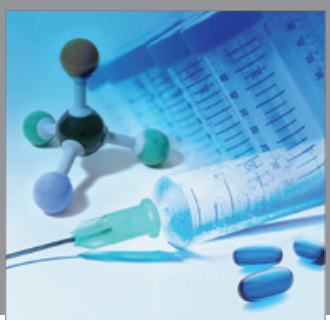

International Journal of

Medicinal Chemistry

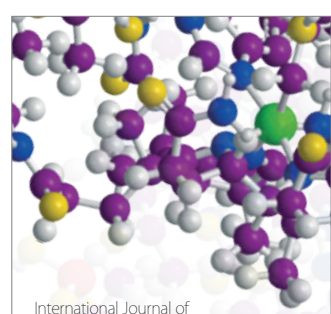

Carbohydrate Chemistry

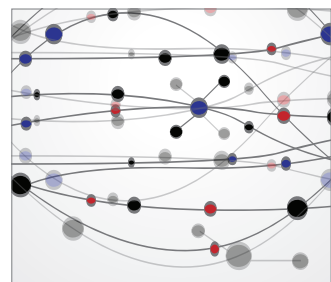

The Scientific World Journal
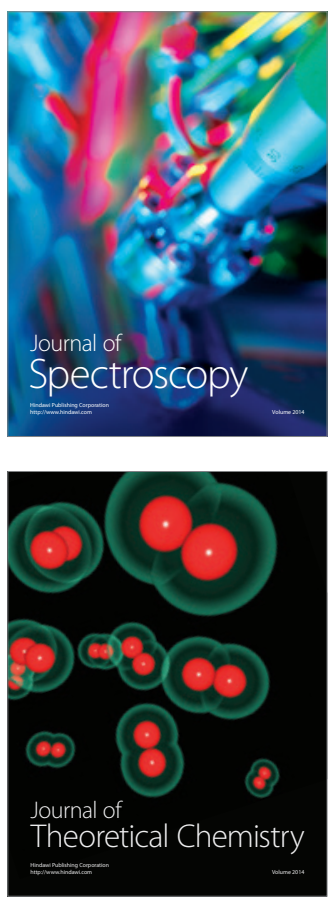
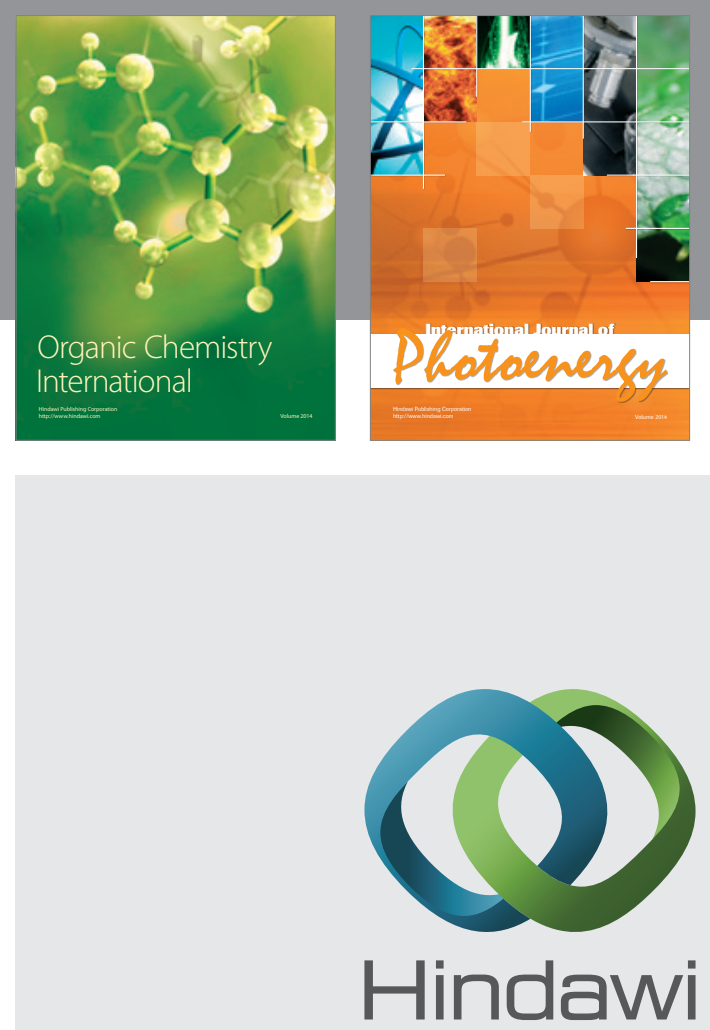

Submit your manuscripts at

http://www.hindawi.com
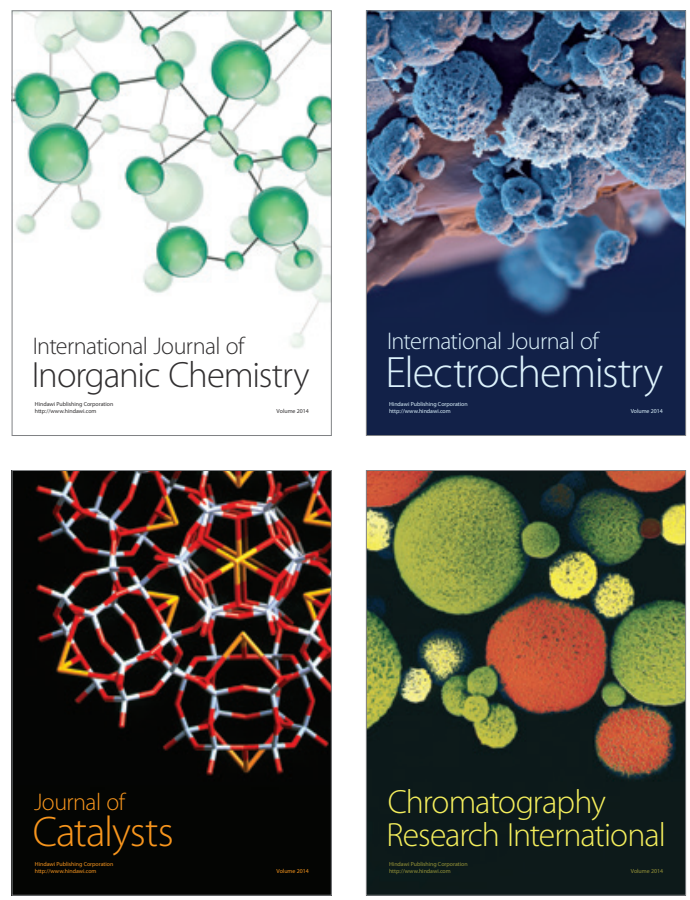
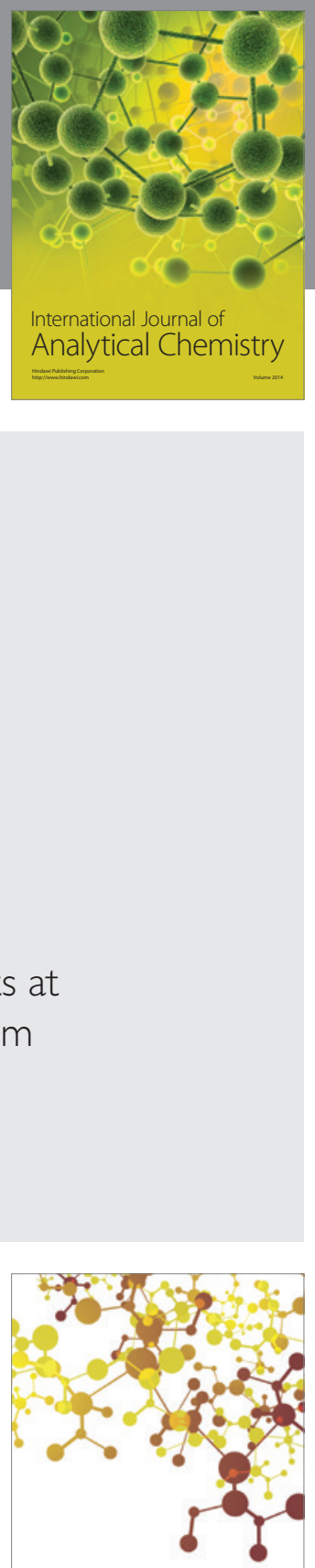

Journal of

Applied Chemistry
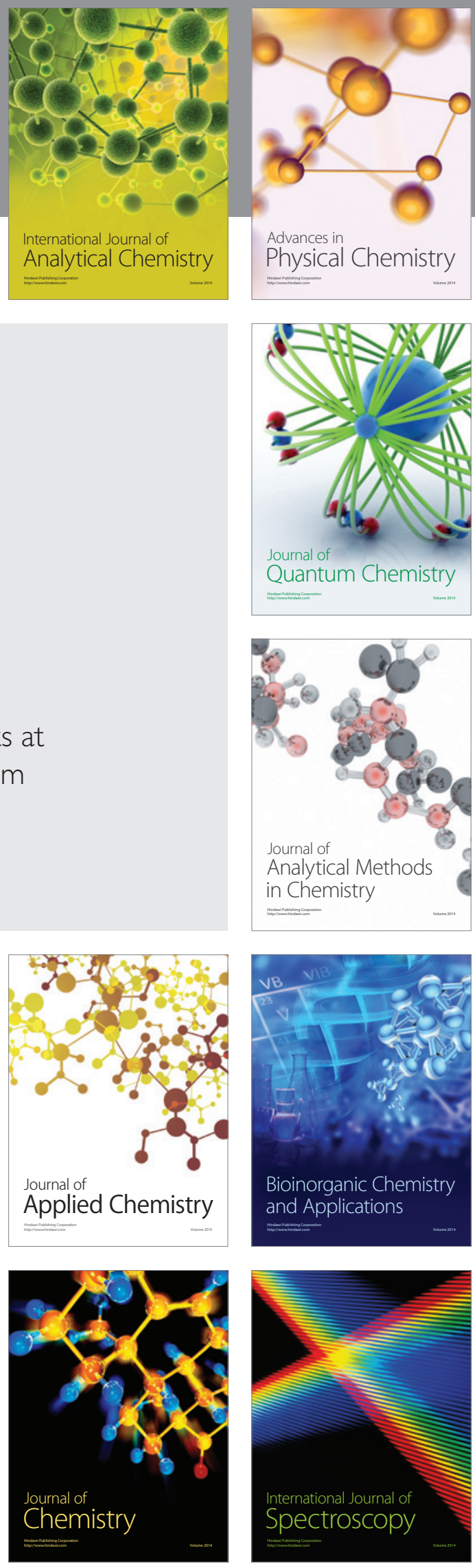